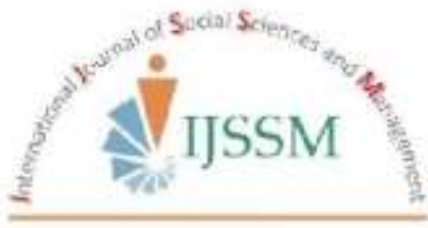

International Journal of Social Sciences and Management

Research Article

\title{
THE IMPACT OF TRANSFORMATIONAL LEADERSHIP STYLE ON NURSE’S SELF-ESTEEM OF PUBLIC HOSPITALS OF LAHORE PAKISTAN
}

\author{
Muhammad Afzal*, Ali Waqas, Amina Farooq and Muhammad Hussain \\ The University of Lahore, Pakistan \\ *Corresponding author's email: muhammad.afzal@1sn.uol.edu.pk
}

\begin{abstract}
Efficient health services require the self-confident and capable medical staff. This milestone cannot be achieved without the flexible and supportive leadership. In the developing countries, health sector has been facing the critical issues like lack of staff, management focus, health facilities and other challenges. Therefore, it is the need of time that supportive and flexible environment should be provided to the nurses so that the self-esteem can be increased and efficient health services can be ensured. Moreover, leaders play a vital role to create the flexible environment that increases the nurse's self-esteem. Thus, the current study investigates the influence of transformational leadership style on the nurse's self-esteem of public hospitals of Lahore, Pakistan. The self-administered questionnaire was distributed to 200 nurses of two major public hospitals (Mayo hospital and Jinnah hospital) of Lahore, Pakistan through simple random sampling. The results of the current study reveal that transformational leadership style has significant and positive relationship with nurse's self-esteem. Therefore, health care sector authorities should adopt the transformational leadership style to enhance the nurse's self-esteem in their sector to ensure the efficient health care services. Furthermore, limitations and recommendations are given in the last chapter.
\end{abstract}

Keywords: Transformational leadership style; Self-esteem; nursing leadership

\section{Introduction}

Nurses face diverse challenges while providing the heath care facilities, so, self-confidence and strong believe on the self-capabilities help them to cope with these challenges. Thus, employee's self-esteem plays a crucial role in the efficient health care services. Moreover, self-esteem is associated with the encouragement of head nurses and it ultimately influence the patient care (George, 2016). Nurses with high self-esteem perform better at the workplace (Valizadeh et al., 2016).

However, self-esteem is a major problem in the developing countries due to lack of focus and resources. Generally, the attainment of self-concept from the work environment becomes the reason of high self-esteem (Shimizu et al., 2004). In addition, employee's self-esteem has close association with the supportive leadership at the workplace (Sasat et al., 2002). Therefore, the role of leadership in the nurse's self-esteem cannot be ignored. Previously, there has been remain an intense focus on the nursing leadership and still remain considerable concerns. The failure of the nursing leadership effects both clinical outcomes and quality of the health care services (Garling 2008; Jackson et al. 2013). In addition, leadership style has key importance to build the supportive and encouraging workplace. There are different leadership styles like transformational leadership style, transaction leadership style, democratic leadership style, authoritarian leadership and servant leadership style etc. but transformational leadership style is one of the most effective leadership styles. The study emphasizes that leaders prefer transformational leadership style to attain the organizational benefits (Matzler et al., 2015).

The studies have mentioned that the focus on the nurses' self-esteem is not documented well in the developing countries and further research work should emphasize on the issues of the nurse's in the developing countries. The study noted that the concept of self-esteem has not been investigated widely in the field of nurses (Judge et al., 2001). Thus, the current study investigates the effect of transformational leadership style on the nurse's self-esteem of public hospitals of Lahore, Pakistan.

\section{Significance of Study}

The current study investigates the effect of transformational leadership style on nurse's self-esteem of public hospitals of Lahore, Pakistan. This study enhances the knowledge of the health care professionals regarding the relationship between transformational leadership style and nurses' self- 
esteem. In addition, this study will increase the awareness of the healthcare administration regarding the importance of nurse's self-esteem. Moreover, public and private health care providers can increase the efficiency of the sector through the study results.

\section{Literature Review}

Organizations make plan to achieve the organizational goals and leadership plays a vital role in the attainment of these goals (Mason et al., 2014). Leadership is a process to influence the employees to achieve the organizational goals (Siow et al., 2013). Thus, leaders play an important role to achieve the organizational aims and objectives (Muenjohn, 2015). Moreover, transformational leadership empowers the employees to build the good relationship and to meet the organizational goals (Giltinane, 2013).

However, transformational leadership style comprises of four categorize: individualized consideration, intellectual stimulation, inspirational motivation and idealized influence (Bass, 1997). Leader's personal attention to the followers describes the individualized consideration, intellectual stimulation enables the followers to think and behave in rational manner, inspirational motivation depicts the motivation and positivity among the employees and idealized influence portrays the vision and mission to the employees (Dubinsky et al., 1995).

Transformational leadership style motivate the followers to move beyond the self-interest and work for the organizational benefits (Wang et al., 2011).Transformational leadership is the relationship of inspiration between the leaders and employees which motivate them to think in the modesty (Krishnan, 2012). Moreover, transformational leadership enhances the interaction between leaders and subordinates (Cummings et al., 2010). Likewise, transformational leadership style is preferred among the nursing profession (Mittal et al., 2015). The use of transformational leadership style depends on the nursing leaders' skill to motivate others towards growth (Doody et al., 2012).

Furthermore, transformational leadership share the vision with employees and create the sense of ownership among the followers (Pieterse et al., 2010). Leaders provide the challenging tasks to the followers and understand the individuals and increases the self-esteem (Bass et al., 2006). However, self-esteem determines the self-evaluation of the person (Rosenberg, 1965). Similarly, the study noted that self-esteem describes the individual's believes on his/her capability (Pierce et al., 2015). Nurse's self-esteem involves the real self, empathy, ability to cooperate with colleagues (Ebrahimi et al., 2016). Thus, the person with higher self-esteem consider himself as the person of worth (Rosenberg, 1979).
Furthermore, employee's self-esteem has association with key outcomes such as satisfaction and job performance (Baumeister et al., 2003; Gardner and Pierce, 1998). The studies have given more attention to the role self-esteem and it has become clear that self-esteem is not only an important psychological need but also an important economic need (McAllister and Bigley, 2002; Branden and Bennis, 1998). Employee's self-esteem plays an important part while reasoning, decision making and action regulation (Wiesenfeld et al., 2000). Moreover, role of self-esteem contributes in shaping the attitude and behaviors of nurses like increase in the motivation and social responsibility characteristics while decrease in the violence occur (Iacobucci et al., 2013).

However, employee's relationship with colleagues and leaders significantly influence the self-esteem (McAllister and Bigley, 2002). Likewise, charismatic leadership has significant association with the employee's self-esteem (Shamir et al., 1993). Leader's consistency in the rules for followers results into higher employee's self-esteem (Cremer, 2003b). If leaders deal with followers with respect and give value then in return the higher self-esteem of the followers can be achieved (Koper et al., 1993).

In addition, transformational leadership style has been widely adopted in the nursing profession and results into positive clinical outcomes (Hutchinson et al., 2013). The transformational leadership has significant positive relationship with employee's self-esteem (Kim et al., 2016; Vito et al., 2014). Likewise, the study noted that transformational leadership positively effects on nurses self-esteem and results in better work performance (Casida et al., 2011). Moreover, transformational leadership enhance the follower's self-esteem and motivates them to give their best (Wang et al. 2011). Therefore, leaders with high confidence also develop the confidence in the followers (Hu et al., 2012).

\section{Study Framework}

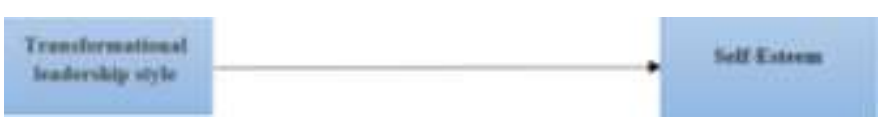

Fig. 1: Research Model

\section{Hypothesis}

H0: Transformational leadership style has no association with nurse's self-esteem.

H1: Transformational leadership style has positive association with nurse's self-esteem.

\section{Research Methodology}

The current study investigates the relationship between transformational leadership style and nurse's self-esteem of the public hospitals of Lahore, Pakistan. The valid and self- 
administered questionnaires based on 5-point Likert scale was adopted for transformational leadership style (Drenth, 2009) and self-esteem (Rosenberg, 1965). Total 200 questionnaires were distributed to the nurses (Inclusion criteria: nurses and head nurses) of the public hospitals of Lahore, Pakistan through simple random sampling of which 170 were received ( $85 \%$ response rate). Inclusion criteria were nurses and head nurses. In addition, reliability and validity of the instruments was analyzed through Cronbach alpha and KMO and Bartlett's test respectively. Likewise, correlation and regression analysis was also performed through SPSS 21.

\section{Results}

\section{Demographic Analysis}

To investigate the relationship among the interest variables the data was collected through the nurses of public hospitals of Lahore, Pakistan. The demographic data of the current study includes detail information about the nurses' gender, age, marital status, qualification and stay in organization which is given in the following. Moreover, correlation and regression analysis was also performed through SPSS 21.

\section{Gender}

Table 1 shows that $100 \%$ data was collected from only female staff nurses.

Table 1: Gender

\begin{tabular}{|l|l|l|l|l|}
\hline & Frequency & Percent & $\begin{array}{l}\text { Valid } \\
\text { Percent }\end{array}$ & $\begin{array}{l}\text { Cumulative } \\
\text { Percent }\end{array}$ \\
\hline Valid FEMALE & 170 & 100.0 & 100.0 & 100.0 \\
\hline
\end{tabular}

\section{Age}

Table 2 shows that $41.8 \%$ of the respondents were belong to the age group of $18-25$ years, $48.2 \%$ of the respondents were from the age group of $25-35$ years, $8.8 \%$ of the respondents were from age group of 35-50 years and only $1.2 \%$ of the respondents were above 50 -years of age.

\section{Marital Status}

Table 3 shows the marital status of the respondent nurses. The results reveal that $58.2 \%$ of the nurses were single and $41.8 \%$ of the nurses were married.
Table 2: Age

\begin{tabular}{|c|c|c|c|c|c|}
\hline & & Frequency & Percent & $\begin{array}{l}\text { Valid } \\
\text { Percent }\end{array}$ & $\begin{array}{l}\text { Cumulative } \\
\text { Percent }\end{array}$ \\
\hline Valid & $\begin{array}{l}18-25 \\
25-35 \\
35 \_50 \\
\text { ABOVE } \\
50 \\
\text { Total }\end{array}$ & $\begin{array}{l}71 \\
82 \\
15 \\
2 \\
170\end{array}$ & $\begin{array}{l}41.8 \\
48.2 \\
8.8 \\
1.2 \\
100.0\end{array}$ & $\begin{array}{l}41.8 \\
48.2 \\
8.8 \\
1.2 \\
100.0\end{array}$ & $\begin{array}{l}41.8 \\
90.0 \\
98.8 \\
100.0\end{array}$ \\
\hline
\end{tabular}

Table 3: Marital Status

\begin{tabular}{|c|c|c|c|c|c|}
\hline & & Frequency & Percent & $\begin{array}{l}\text { Valid } \\
\text { Percent }\end{array}$ & $\begin{array}{l}\text { Cumulative } \\
\text { Percent }\end{array}$ \\
\hline \multirow{3}{*}{ Valid } & SINGLE & 99 & 58.2 & 58.2 & 58.2 \\
\hline & MARRIED & 71 & 41.8 & 41.8 & 100.0 \\
\hline & Total & 170 & 100.0 & 100.0 & \\
\hline
\end{tabular}

\section{Qualification}

Table 4 shows that $97.6 \%$ of the respondents have completed nursing diploma and only $2.4 \%$ of the respondent nurses had any other education.

Table 4: Qualification

\begin{tabular}{|ll|l|l|l|l|}
\hline & $\begin{array}{l}\text { Frequenc } \\
\mathrm{y}\end{array}$ & $\begin{array}{l}\text { Percen } \\
\mathrm{t}\end{array}$ & $\begin{array}{l}\text { Valid } \\
\text { Percen } \\
\mathrm{t}\end{array}$ & $\begin{array}{l}\text { Cumulativ } \\
\mathrm{e} \text { Percent }\end{array}$ \\
\hline Vali & $\begin{array}{l}\text { NURSING } \\
\text { DIPLOM } \\
\mathrm{d}\end{array}$ & 166 & 97.6 & 97.6 & 97.6 \\
& $\begin{array}{l}\text { OTHERS } \\
\text { Total }\end{array}$ & 4 & 2.4 & 2.4 & 100.0 \\
\hline
\end{tabular}

\section{Stay in Organization}

Table 5 shows the respondent nurses' stay in the organization. The results show that $9.4 \%$ of the nurses have joined the hospital within last one year, $60.0 \%$ of the nurses were working in the hospitals from the last 1-5years, $21.8 \%$ of the nurses were working in the hospital from 6-10 years and only $8.8 \%$ of the nurses were part of the hospitals from more than 10 years.

Table 5: Stay in hospital

\begin{tabular}{|c|l|l|l|l|}
\hline & Frequency & Percent & Valid Percent & Cumulative Percent \\
\hline LESS THAN 1 YEAR & 16 & 9.4 & 9.4 & 9.4 \\
1-5 YEAR & 102 & 60.0 & 60.0 & 69.4 \\
Valid 6-10 YEAR & 37 & 21.8 & 21.8 & 91.2 \\
ABOVE 10 YEAR & 15 & 8.8 & 8.8 & 100.0 \\
Total & 170 & 100.0 & 100.0 & \\
\hline
\end{tabular}




\section{Transformational and Self-Esteem (Descriptive Statistics)}

Table 6 shows the means and standard deviations of transformational leadership style and nurse's self-esteem. Transformational leadership style has the mean value of 4.133 which depicts that majority of the nurses were agree and .70 standard deviation represents the $70 \%$ variation among the responses. Likewise, results in table 6 shows that nurses' self-esteem has the mean value of 4.23 which represents the majority of the nurses were agree and .571 standard deviation depicts that $57 \%$ variation among the response of the nurses of public hospitals of Lahore, Pakistan.

Table 6: Means and Standard Deviation

\begin{tabular}{|l|l|l|l|}
\hline & N & Mean & Std. Deviation \\
\hline Self-esteem & 170 & 4.23 & .571 \\
Trans_Lshp & 170 & 4.1333 & .70573 \\
Valid N (list wise) & 170 & & \\
\hline
\end{tabular}

Trans_Lshp $=$ Transformational leadership

\section{Reliability and Validity}

Cronbach's alpha is the most commonly used measure of the scale's reliability (Cortina, 1993). However, Cronbach's alpha value above 0.70 is considered to be the acceptable indicator of internal consistency reliability. Table 7 shows the reliability of transformational leadership style and nurse's self-esteem. The results in table 4 shows the alpha value of .77 for transformational leadership style and .90 for nurse's self-esteem which is within the acceptable range of reliability. Thus, both scales (transformational leadership style and self-esteem) of the current study are reliable.

Table 7: Reliability Statistics

\begin{tabular}{|l|l|l|}
\hline Variable & Cronbach's Alpha & N of Items \\
\hline Trans_Lshp & .770 & 5 \\
\hline Self-esteem & .907 & 12 \\
\hline
\end{tabular}

\section{KMO Bartlett's test}

Table 8 shows the validity of the scales of the current study. The results in table 8 shows that KMO value is .727 which is above .50 and Bartlett's test is also significant $(\mathrm{p}<.05)$, thus, both the scales (transformational leadership style and self-esteem) are valid.

Table 8: KMO and Bartlett's Test

\begin{tabular}{|c|c|c|}
\hline \multicolumn{2}{|c|}{$\begin{array}{l}\text { Kaiser-Meyer-Olkin Measure of Sampling } \\
\text { Adequacy. }\end{array}$} & .727 \\
\hline \multirow{3}{*}{ Bartlett's Test of Sphericity } & Approx. Chi-Square & 274.694 \\
\hline & Df & 10 \\
\hline & Sig. & .000 \\
\hline
\end{tabular}

\section{Pearson Correlation}

Table 9 demonstrates the correlation between the transformational leadership style and nurse's self-esteem. The results show that transformational leadership style has significant and positive correlation $(r=.635, \mathrm{p}<.05)$ with nurse's self-esteem.

Table 9: Correlations

\begin{tabular}{|c|c|c|c|}
\hline & & Self-esteem & Trans_Lshp \\
\hline \multirow{4}{*}{ Self_Esteem } & Pearson Correlation & 1 & $.635^{* *}$ \\
\hline & Sig. (2-tailed) & & .000 \\
\hline & $\mathrm{N}$ & 170 & 170 \\
\hline & Pearson Correlation & $.635^{* *}$ & 1 \\
\hline \multirow[t]{2}{*}{ Trans_Lshp } & Sig. (2-tailed) & .000 & \\
\hline & $\mathrm{N}$ & 170 & 170 \\
\hline
\end{tabular}

**. Correlation is significant at the 0.01 level (2-tailed).

\section{Regression Analysis}

Table 10 shows the relationship between transformational leadership style and nurse's self-esteem. In addition, .39 value of R square depicts that $39 \%$ of total variations in the dependent variable is explained by the predictor. Similarly, $\mathrm{F}=113.39$ and $\mathrm{P}<0.05$ described that current model is significant as it causes change in the dependent variable. Thus, hypothesis $\mathrm{H} 1$ of the current study is supported that transformational leadership style has positive association with nurse's self-esteem. Moreover, Table 10 unveiled the degree of freedom (df) at relevant significance level.

Table 11 reveals the level of significance either it is accepted or not. The results show that the level of significance is under .000 as the value of "P" is less than .05 , thus, it Is accepted that transformational leadership style has positive influence on nurse's self-esteem.

Table 10: Model Summary

\begin{tabular}{|l|l|l|l|l|l|l|l|l|l|l|}
\hline Model & $\mathrm{R}$ & \multirow{2}{*}{$\begin{array}{l}\mathrm{R} \\
\text { Square }\end{array}$} & $\begin{array}{l}\text { Adjusted } \mathrm{R} \\
\text { Square }\end{array}$ & $\begin{array}{l}\text { Std. Error of the } \\
\text { Estimate }\end{array}$ & \begin{tabular}{l} 
Change Statistics \\
\cline { 5 - 10 } \\
R Square
\end{tabular} & $\begin{array}{l}\text { F } \\
\text { Change }\end{array}$ & df1 & df2 & $\begin{array}{l}\text { Sig. F } \\
\text { Change }\end{array}$ & $\begin{array}{l}\text { Durbin- } \\
\text { Watson }\end{array}$ \\
\hline 1 & $.635^{\mathrm{a}}$ & .403 & .399 & .443 & .403 & 113.399 & 1 & 168 & .000 & 1.256 \\
\hline
\end{tabular}

a. Predictors: (Constant), Trans_Lshp

b. Dependent Variable: Self_Esteem 
Table 11: ANOVA ${ }^{\mathrm{a}}$

\begin{tabular}{l|l|r|r|r|r|c|}
\hline \multicolumn{2}{|l|}{ Model } & Sum of Squares & \multicolumn{1}{c|}{ df } & Mean Square & F & Sig. \\
\hline \multirow{3}{*}{1} & Regression & 22.213 & 1 & 22.213 & 113.399 & $.000^{\mathrm{b}}$ \\
\cline { 2 - 7 } & Residual & 32.908 & 168 & .196 & & \\
\cline { 2 - 7 } & Total & 55.121 & 169 & & & \\
\hline
\end{tabular}
a. Dependent Variable: Self_Esteem
b. Predictors: (Constant), Trans_Lshp

Table 12: Coefficients

\begin{tabular}{|c|c|c|c|c|c|c|}
\hline \multicolumn{2}{|c|}{ Model } & \multicolumn{2}{|c|}{ Unstandardized Coefficients } & Standardized Coefficients & t & \multirow{2}{*}{ Sig. } \\
\cline { 2 - 6 } & B & Std. Error & Beta & & \\
\hline \multirow{2}{*}{1} & (Constant) & 2.107 & .202 & & 10.418 & .000 \\
\cline { 2 - 7 } & Trans_Lshp & .514 & .048 & .635 & 10.649 & .000 \\
\hline
\end{tabular}

a. Dependent Variable: Self_Esteem

Table 12 mentions the beta value which epitomize the influence of the transformational leadership style on nurses' self-esteem. The results show that the beta value of .635 which emphasizes that transformational leadership style has strong influence on the nurse's self-esteem. So, $63.5 \%$ of the variation in the nurse's self-esteem has explained by the transformational leadership style at the significant level $(p<0.5)$. However, beta value of .514 emphasizes that one unit increase in the transformational leadership style will cause .514 increase in the nurse's self-esteem.

\section{Discussion}

The current study investigates the influence of transformational leadership style on nurses' self-esteem. SPSS 21 was used to apply Pearson correlation and linear regression analysis among the study variables. Table 9 shows that transformational leadership has significant and positive relationship with nurse's self-esteem ( $r=.635$, $\mathrm{p}<0.05)$. Likewise, table 12 shows that transformational leadership style has significant and positive association with nurse's self-esteem. Thus, H1 is supported that transformational leadership style has significant positive relationship with nurse's self-esteem of public hospitals of Lahore, Pakistan. Moreover, table 12 mentions that $\mathrm{A}=$ 2.107 is average value of the nurse's self-esteem when transformational leadership is zero. The results of the current study are in line with the previous studies which claim that transformational leadership has strong influence on employee's self-esteem (Chan et al., 2013). Furthermore, the current study results emphasize that transformational leadership style becomes the reason of nurse's higher self-esteem and it should be implemented in the health care sector.

\section{Conclusion}

This study has analyzed the influence of transformational leadership style on nurse's self-esteem of public hospitals of Lahore, Pakistan. The results of the current study reveal that transformational leadership style has significant and positive influence on the nurse's self-esteem. Therefore, healthcare sector should implement the transformational leadership style to enhance the nurse's self-esteem, so that the efficient and effective health care services can be provided to the public.

\section{Limitations and Recommendations}

The current study analyzes the relationship of transformational leadership style and nurse's self-esteem of public hospitals of Lahore, Pakistan only due to lack of time and other constraints. Further, studies should analyze this relation in the other regions of Pakistan. Likewise, access to the nurse's and willingness was the hurdle for the data collection of the current study. Similarly, nurse's bear a lot of burden at the workplace and couldn't give time to fill the questionnaire. Moreover, there may exists any other variable which can affect the relationship between the leadership and nurse's self-esteem which should also be investigated in the further studies like work environment, justice etc.

\section{References}

Bass BM (1997) Does the transactional-transformational leadership paradigm transcend organizational and national boundaries? American psychologist 52(2): 130.

Bass BM and Riggio RE (2006) Transformational Leadership, Lawrence Erlbaum Associates. Mahwah, NJ.

Baumeister RF, Campbell JD, Krueger JI and Vohs KD (2003) Does high self-esteem cause better performance, interpersonal success, happiness, or healthier lifestyles? Psychological science in the public interest 4(1): 1-44.

Branden N and Bennis GW (1998) Self-esteem at work: How confident people make powerful companies (Vol. 17). San Francisco, CA: Jossey-Bass. 
Casida J and Parker J (2011) Staff nurse perceptions of nurse manager leadership styles and outcomes. Journal of Nursing Management 19(4): 478-486.

Cortina JM (1993) What is coefficient alpha? An examination of theory and applications. Journal of applied psychology 78(1): 98.

Cummings GG, MacGregor T, Davey M, Wong CA, Lo E, Muise M and Stafford E (2010) Leadership styles and outcome patterns for the nursing workforce and work environment: a systematic review. International journal of nursing studies 47(3): 363-385.

De Cremer D (2003) Why inconsistent leadership is regarded as procedurally unfair: the importance of social self-esteem concerns. European Journal of Social Psychology 33(4): 535-550.

Doody O and Doody CM (2012) Transformational leadership in nursing practice.

Drenth J (2009) The ingredients for a committed workforce.

Dubinsky AJ, Yammarino FJ, Jolson MA and Spangler WD (1995) Transformational leadership: An initial investigation in sales management. Journal of Personal Selling and Sales Management 15(2): 17-31.

Ebrahimi H, Hassankhani H, Negarandeh R, Jeffrey C and Azizi A (2016) Violence against new graduated nurses in clinical settings A qualitative study. Nursing ethics, 0969733015624486.

Gardner DG and Pierce JL (1998) Self-esteem and self-efficacy within the organizational context an empirical examination. Group and Organization Management 23(1): 48-70.

Garling, P. (2008). Final Report of the Special Commission of Inquiry into Acute Care Services

Giltinane CL (2013) Leadership styles and theories. Nursing Standard 27(41): 35-39.

Hu J, Wang Z, Liden RC and Sun, J. (2012). The influence of leader core self-evaluation on follower reports of transformational leadership. The leadership quarterly 23(5): 860-868.

Hutchinson M and Jackson D (2013) Transformational leadership in nursing: towards a more critical interpretation. Nursing Inquiry 20(1): 11-22.

Iacobucci TA, Daly BJ, Lindell D and Griffin MQ (2013) Professional values, self-esteem, and ethical confidence of baccalaureate nursing students. Nursing ethics 20(4): 479490.

in NSW Hospitals. Sydney: Department of Attorney General and Justice.

Jackson D, Hutchinson M, Peters K, Luck L and Saltman D (2013) Understanding avoidant leadership in health care: Findings from a secondary analysis of two qualitative studies. Journal of nursing management 21(3): 572-580.

Judge TA and Bono JE (2001) Relationship of core selfevaluations traits-self-esteem, generalized self-efficacy, locus of control, and emotional stability-with job satisfaction and job performance: A meta-analysis. Journal of applied psychology 86(1): 80.

Kim WS, Cho HH and Kwon S (2016) The Influence of Terminal Care Performance, Death Anxiety and Self-Esteem on Terminal Care Stress of Geriatric Hospital Nurses. Korean Journal of Hospice and Palliative Care 19(2): 154-162.

Koper G, Van Knippenberg D, Bouhuijs F, Vermunt R and Wilke H (1993) Procedural fairness and self-esteem. European Journal of Social Psychology 23(3): 313-325.

Krishnan VR (2012) Transformational leadership and personal outcomes: empowerment as mediator. Leadership and Organization Development Journal 33(6): 550-563.

Mason C, Griffin M and Parker S (2014) Transformational leadership development: Connecting psychological and behavioral change. Leadership and Organization Development Journal 35(3): 174-194.

Matzler K, Strobl A, Thurner N and Füller J (2015) Switching experience, customer satisfaction, and switching costs in the ICT industry. Journal of Service Management 26(1): $117-136$

McAllister DJ and Bigley GA (2002) Work context and the definition of self: How organizational care influences organization-basei self-esteem. Academy of Management Journal 45(5): 894-904.

Mittal S and Dhar RL (2015) Transformational leadership and employee creativity: mediating role of creative selfefficacy and moderating role of knowledge sharing. Management Decision 53(5): 894-910.

Muenjohn N (2015) Transformational leadership: The influence of culture on the leadership behaviours of expatriate managers. International Journal of Business and information 2(2).

Pierce JL, Gardner DG and Crowley C (2015) Organization-based self-esteem and well-being: empirical examination of a spillover effect. European Journal of Work and Organizational Psychology 1-19.

Pieterse AN, Van Knippenberg D, Schippers M and Stam D (2010) Transformational and transactional leadership and innovative behavior: The moderating role of psychological empowerment. Journal of Organizational Behavior 31(4): 609-623.

Rosenberg M (1965) Rosenberg self-esteem scale (RSE). Acceptance and commitment therapy. Measures package, 61.

Rosenberg M (1979) Concerning the self. New Yoric: Basic Books.

Sasat S, Burnard P, Edwards D, Naiyapatana W et al. (2002) Selfesteem and student nurses: A cross-cultural study of nursing students in Thailand and the UK. Nursing and health sciences 4(1-2): 9-14.

Shamir B, House RJ and Arthur MB (1993) The motivational effects of charismatic leadership: A self-concept based theory. Organization science 4(4): 577-594. 
Shimizu T, Kubota S, Mishima N and Nagata S (2004). Relationship between self-esteem and assertiveness training among Japanese hospital nurses. Journal of Occupational Health 46(4): 296-298.

Siow E and Ng J (2013) Internal migration of nurses in the united states: migratory prompts and difference in job satisfaction between migrants and non-migrants. Nursing Economics 31(3): 128.

Valizadeh L, Zamanzadeh V, Gargari RB, Ghahramanian A, Tabrizi FJ and Keogh B (2016) Pressure and protective factors influencing nursing students' self-esteem: A content analysis study. Nurse education today 36: 468472 .
Vito GF, Higgins GE and Denney AS (2014) Transactional and transformational leadership: An examination of the leadership challenge model. Policing: An International Journal of Police Strategies and Management 37(4): 809822.

Wang G, Oh IS, Courtright SH and Colbert AE (2011) Transformational leadership and performance across criteria and levels: A meta-analytic review of 25 years of research. Group and Organization Management 36(2): 223-270.

Wiesenfeld BM, Brockner J and Thibault V (2000) Procedural fairness, managers' self-esteem, and managerial behaviors following a layoff. Organizational Behavior and Human Decision Processes 83(1): 1-32. 